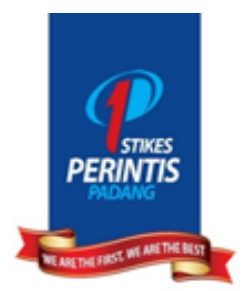

Contents list available at JKP website

Jurnal Kesehatan Perintis (Perintis's Health Journal)

Journal homepage: https://jurnal.stikesperintis.ac.id/index.php/JKP

\title{
Kualitas Hidup Caregiver Skizofrenia: A Cross Sectional Study
}

\author{
Aldo Yuliano Mas Putra* ${ }^{* 1}$, Yuli Permata Sari ${ }^{2}$, Dia Resti Dewi Nanda Demur ${ }^{1}$ \\ ${ }^{1}$ Sekolah Tinggi Ilmu Kesehatan Perintis Padang, Sumatera Barat, Indonesia \\ ${ }^{2}$ Universitas Muhammadyah Sumatera Barat, Indonesia
}

Article Information :

Submission:Jun 18, 2020; Revised:Jul 11, 2020; Accepted:Jul 11, 2020; Available online:Jul 12, 2020

${ }^{*}$ Corresponding author : aldoyuliano@ymail.com

\begin{abstract}
ABSTRAK
Penderita Skizofrenia di rumah membutuhkan bantuan dan pertolongan dalam memenuhi kebutuhannya sehari-hari. Caregiver memiliki stressor yang lebih tinggi dalam merawat anggota keluarga dengan Skizofrenia. Banyak caregiver yang tidak mampu mengantisipasi masalah tersebut dan berdampak terhadap kondisi psikologis, kesehatan mental dan kualitas hidup mereka. Tujuan penelitian adalah untuk mengidentifikasi hubungan antara beban dengan kualitas hidup pada caregiver klien skizofrenia. Penelitian ini merupakan penelitian deskriptif korelasi dengan mengunakan pendekatan cross sectional yang melibatkan 79 caregiver pada klien skizofrenia di wilayah kerja Puskesmas Suliki Kabupaten Lima Puluh Kota. Instrumen yang digunakan dalam penelitian ini adalah Zarit Burden Interview untuk beban caregiver dan WHOQOL-BREF untuk kualitas hidup caregiver. Berdasarkan hasil analisis didapatkan bahwa caregiver memiliki beban ringan $(39,2 \%)$ dan kualitas hidup caregiver rendah (60,8\%). Uji statistik Chi-Square membuktikan adanya hubungan yang signifikan antara dimensi beban; beban fisik $(0,033)$, beban emosional $(0,008)$, beban ekonomi $(0,002)$, beban sosial $(0,047)$ dan beban caregiver mempunyai hubungan yang signifikan dengan kualitas hidup caregiver ( $P$ value $=0,004)$. Disarankan bagi Puskesmas agar memiliki program untuk meningkatkan koping keluarga melalui strategi pemecahan masalah bersama anggota keluarga, memberikan dukungan spiritual dan sosial dalam merawat anggota keluarga dengan Skizofrenia.
\end{abstract}

Kata kunci : beban, caregiver, kualitas hidup

\section{ABSTRACT}

Schizophrenics at home need help and help in meeting their daily needs. Caregiver has a higher stressor in caring for family members with Schizophrenia. Many caregivers are unable to anticipate these problems and have an impact on their psychological condition, mental health and quality of life. The aim of the study was to identify the relationship between burden and quality of life in schizophrenic client caregivers. This research is a descriptive correlation study using a cross sectional approach involving 79 caregivers in schizophrenic clients in the working area of the Suliki Health Center in Lima Puluh Kota. The instruments used in this study were Zarit Burden Interview for caregiver loads and WHOQOL-BREF for caregiver quality of life. Based on the results of the analysis found that caregivers have a light burden (39.2\%) and caregiver quality of life is low (60.8\%). Chi-Square statistical tests prove a significant relationship between load dimensions; physical burden (0.033), emotional

( Jurnal Kesehatan Perintis (Perintis's Health Jornal)-ISSN : 2622-4135. All rights reserved 
burden (0.008), economic burden (0.002), social burden (0.047) and caregiver burden have a significant relationship with quality of caregiver life $(X 2=0.004)$. It is recommended for Puskesmas to have programs to improve family coping through problem solving strategies with family members, providing spiritual and social support in caring for family members with Schizophrenia.

Keywords: burden, caregiver, quality of life

\section{PENDAHULUAN}

Merawat klien Skizofrenia dirumah memiliki durasi perawatan yang panjang, timbulnya gejala yang terus menerus, sering kambuh sehingga menimbulkan beban dalam merawat klien. Ketika perawatan dilakukan di luar rumah sakit maka akan berpengaruh terhadap anggota keluarga atau kerabat sebagai orang yang melakukan pelayanan utama atau Caregiver (Fitrikasari et al., 2012). Menurut (Yuli, 2018) faktor-faktor yang berhubungan dengan kekambuhan klien gangguan jiwa di rumah adalah ketidakpatuhan minum obat, dukungan keluarga, dan dukungan petugas kesehatan.

Caregiver harus mengeluarkan tenaga yang tidak ternilai untuk memberikan perawatan dan membantu klien dengan skizofrenia, banyak dari caregiver yang tidak mampu mengantisipasi masalah tersebut dan berdampak terhadap kondisi psikologis, kesehatan mental dan kualitas hidup mereka (Lam, NG, 2013). Rendahnya kualitas hidup caregiver dapat memicu perilaku kekerasan dan penelantaran dalam merawat anggota keluarga yang sakit.

Skizofrenia sebagai suatu penyakit otak persisten dan serius yang menyebabkan prilaku psikotik, pemikiran konkrit dan memiliki kesulitan dalam memproses informasi, hubungan interpersonal serta memecahkan masalah (Stuart, 2013). Marnie L. Kramer-Kile et al., (2014) menyatakan bahwa caregiver adalah seseorang baik keluarga, teman atau hubungan lain yang memberi perawatan dan dukungan fisik, praktis dan emosional kepada klien. Caregiver yang merawat klien dengan penyakit skizofrenia mempunyai pengalaman tekanan psikologis yang kuat dan rasa khawatir dalam proses merawat klien. Pengukuran kualitas hidup bersifat multidimensi yang meliputi dimensi kesehatan fisik, kesejahteraan psikologis, hubungan social hubungan dengan lingkungan. Penurunan kualitas hidup caregiver dipengaruhi oleh beberapa faktor diantaranya faktor yang paling dominan dan secara langsung mempengaruhi kualitas hidup adalah beban (Caqueo, 2009).

Setelah peneliti meninjau penelitian terkait yang dilakukan sebelumnya, peneliti menemukan hal mendukung perlunya dilakukan penelitian tentang hubungan beban dengan kualitas hidup Caregiver klien Skizofrenia dengan melakukan pengambilan data langsung di rumah Caregiver. Penelitian sebelumnya yang dilakukan oleh (Patricia, 2018) tentang faktor-faktor yang berhubungan dengan kualitas hidup Caregiver Skizofrenia didapatkan bahwa sebagian besar kualitas hidup caregiver rendah, terdapat hubungan antara karakteristik; usia; jenis kelamin; status marital; tingkat pendidikan; pekerjaan; penghasilan dan hubungan dengan caregiver dengan kualitas hidup caregiver skizofrenia. Sedangkan penelitian (Fitrikasari et al., 2012) menyimpulkan bahwa sebagian besar caregiver menganggap perawatan terhadap anggota keluarga dengan skizofrenia merupakan beban. Pada umumnya penelitian sebelumnya mengambil sampel di Rumah Sakit Jiwa sedangkan aktivitas caregiver berada di rumah sehingga akan lebih baik penelitian caregiver skizofrenia dilakukan di rumah.

Diperkirakan penderita gangguan jiwa di dunia sebanyak 450 juta jiwa termasuk Skizofrenia (WHO, 2017). Rerata gangguan jiwa di Indonesia mengalami kenaikan yang signifikan. Kenaikan ini terlihat dari kenaikan prevalensi Orang Dengan Gangguan Jiwa (ODGJ) di Indonesia. dari 1,7 pada tahun 2013 menjadi 7 per mil pada tahun 2018. Provinsi Sumatera Barat berada pada urutan ke 7 di Indonesia yakni 10 per mil (Riskesdas, 2018).

Menurut data Dinas Kesehatan Sumatera Barat Tahun 2017, Kabupaten 
Lima Puluh Kota merupakan urutan keempat terbanyak dengan pasien gangguan jiwa (skizofrenia). Berdasarkan studi pendahuluan dan survei ke lapangan yang dilakukan peneliti pada bulan Agustus 2018 diperoleh data bahwa dalam 3 tahun terakhir selalu terjadi peningkatan klien dengan penyakit skizofrenia di Puskesmas Suliki. Berdasarkan hasil wawancara terhadap caregiver yang mengantarkan klien skizofrenia kontrol ulang di Puskesmas Suliki, dari 10 caregiver yang ditemui 8 orang diantaranya mengeluhkan adanya masalah dalam merawat klien keterbatasan dan ketergantungan waktu klien kepada anggota keluarga yang merawat, klien merasa malu dengan teman dan tetangga karena keberadaan klien serta ketakutan klien melakukan kekerasan pada caregiver dan mengeluhkan masalah keuangan seperti biaya untuk akomodasi berobat dan pemenuhan kebutuhan seharihari.

Tujuan penelitian ini adalah untuk mengetahui Hubungan beban dengan kualitas hidup caregiver klien Skizofrenia di wilayah kerja puskesmas Suliki Kabupaten Lima Puluh Kota.

\section{METODE PENELITIAN}

Penelitian ini menggunakan desain deskriptif korelasi dengan pendekatan Cross Sectional. Populasi pada penelitian ini adalah Caregiver klien Skizofrenia di Wilayah Kerja Puskesmas Suliki yang berjumlah 88 orang. Pengambilan data dilakukan secara Total Sampling dengan kriteria inklusi adalah Caregiver klien Skizofrenia yang merawat anggota keluarga yang sakit di rumah yang berusia paling sedikit 17 Tahun, telah merawat klien skizofrenia minimal 6 bulan di rumah. Sedangkan kriteria ekslusi adalah caregiver yang tidak bersedia sebagai sampel, telah pindah dari wilayah kerja Puskesmas Suliki serta Caregiver dengan anggota keluarga yang mengalami Skizofrenia telah meninggal dunia. Sampel pada penelitian ini berjumlah 79 orang, karena 9 orang diantaranya termasuk kedalam kriteria ekslusi.

Kualitas hidup diukur melalui kuesioner World Health Organization Quality of Life (WHO-QOL-BREF) oleh (Skevington and
Lotfy, 2004), sedangkan beban caregiver diukur menggunakan Zarit Burden Interview oleh (Seng et al., 2010). Kedua instrumen ini telah diuji cobakan sebelumnya dan dinyatakan valid, sedangkan untuk pengujian reabilitas untuk WHOQOL-BREF memiliki nilai Alpha Cronbach 0,93 dan ZBI $>0,7$ pada setiap domainnya (Seng et al., 2010), (Skevington and Lotfy, 2004). Jumlah pertanyaan untuk kuesioner kualitas hidup sebanyak 26 item pertanyaan dan hasilnya dikategorikan berdasarkan nilai rata-rata. Sedangkan kuesioner ZBI terdiri atas 22 item pertanyaan yang diukur menggunakan skala linkert dengan rentang score 0 (tidak pernah) - 4 (selalu) yang terdiri atas domain ; beban fisik, beban emosional, beban ekonomi, beban sosial dan beban hubungan keluarga. Proses pengumpulan data dilakukan dengan menghubungi kader jiwa yang telah terdata di Puskesmas Suliki dan bersama kader tersebut peneliti menuju rumah Caregiver. Kemudian peneliti menjelaskan tujuan dan melakukan inform consent. Setelah mendapatkan persetujuan dari Caregiver maka peneliti melakukan pengambilan data dengan wawancara terpimpin menggunakan kuesioner yang telah ditetapkan.

Data diolah secara komputerisasi dan dianalisis dengan ukuran frekuensi untuk mengetahui gambaran setiap variabel dan disajikan dalam tabel distribusi frekuensi, sedangkan menjawab hipotesis menggunakan uji Chi-Square dengan $\mathrm{Cl}$ 95\% untuk melihat hubungan antara beban dengan kualitas hidup caregiver.

\section{HASIL DAN PEMBAHASAN}

Tabel 1 menunjukkan bahwa sebagian besar responden adalah Perempuan $(70,9 \%)$, rentang usia berdasarkan Usia rerata $\pm S D(n=79)$ terbanyak $37-60$ tahun $(75,9 \%)$, Status pernikahan menikah $(80,6 \%)$, Tingkat Pendidikan SMA (54,43\%), tidak bekerja (53,2\%), penghasilan dibawah UMR (60,8\%), memiliki hubungan saudara dengan klien Skizofrenia $(41,7 \%)$.

Distribusi frekuensi beban dan kualitas hidup Caregiver dalam merawat anggota keluarga dengan Skizofrenia pada tabel 2 menunjukkan bahwa terdapat Caregiver 
yang merasakan Beban Ringan yakni $(39,2 \%)$. Sedangkan distribusi frekuensi kualitas hidup caregiver menunjukkan bahwa responden memiliki kualitas hidup rendah $60,8 \%$.

Tabel 1. Distribusi Frekuensi Karakteristik Caregiver; Jenis Kelamin, Kelompok Usia, Status Pernikahan, Tingkat Pendidikan, Pekerjaan, Penghasilan dan Hubungan dengan Klien $(n=79)$

\begin{tabular}{|c|c|c|}
\hline $\begin{array}{c}\text { Karakteristik } \\
\text { Responden } \\
\text { Jenis Kelamin }\end{array}$ & f & $\%$ \\
\hline Laki-laki & 23 & 29,1 \\
\hline $\begin{array}{l}\text { Perempuan } \\
\text { Kelompok Usia }\end{array}$ & 56 & 70,9 \\
\hline $21-36$ & 8 & 10,1 \\
\hline $37-60$ & 60 & 75,9 \\
\hline $\begin{array}{l}>60 \\
\text { Status } \\
\text { Pernikahan }\end{array}$ & 11 & 13,9 \\
\hline Menikah & 70 & 80,6 \\
\hline $\begin{array}{l}\text { Tidak Menikah } \\
\text { Tingkat } \\
\text { Pendidikan }\end{array}$ & 9 & 19,4 \\
\hline SD & 10 & 12,65 \\
\hline SMP & 12 & 13,92 \\
\hline SMA & 42 & 54,43 \\
\hline $\begin{array}{l}\text { PT } \\
\text { Pekerjaan }\end{array}$ & 15 & 18,98 \\
\hline Bekerja & 37 & 46,8 \\
\hline $\begin{array}{l}\text { Tidak Bekerja } \\
\text { Penahasilan }\end{array}$ & 42 & 53,2 \\
\hline Diatas UMR & 31 & 39,2 \\
\hline $\begin{array}{l}\text { Dibawah UMR } \\
\text { Hubungan }\end{array}$ & 48 & 60,8 \\
\hline Anak & 4 & 5,1 \\
\hline Orangtua & 30 & 38 \\
\hline Pasangan & 12 & 15,2 \\
\hline Saudara & 33 & 41,7 \\
\hline
\end{tabular}

Hal ini sejalan dengan penelitian yang dilakukan oleh (Afriyeni and Sartana, 2017) yang menunjukkan beban terbanyak caregiver adalah ringan 43,3\%. Peneliti berpendapat hal ini dipengaruhi oleh karakteristik caregiver yang pada umumnya berada pada rentang usia produktif $37-60$ Tahun dan tidak bekerja $52,3 \%$ sehingga caregiver memiliki strategi koping yang baik dalam merawat anggota keluarga dengan Skizofrenia.
Hasil Penelitian oleh (Rahmani et al., 2019) tentang Strategi Koping Caregiver klien Skizofrenia mengatakan bahwa usia memiliki korelasi yang dignifikan dengan strategi koping. Semakin tinggi usia Caregiver maka semakin mapan dalam menggunakan strategi koping yang berfokus pada masalah. Sehingga mampu menghadapi stressor yang muncul dari anggota keluarga yang sakit.

\begin{tabular}{|c|c|c|}
\hline $\begin{array}{lr}\text { Kualitas } & \text { Hidup } \\
\text { Skizofrenia }(n=79)\end{array}$ & Caregiver & $\mathbf{K}$ \\
\hline $\begin{array}{c}\text { Variabel } \\
\text { Beban Care Giver }\end{array}$ & $f$ & $\%$ \\
\hline Beban Berat & 3 & 3,8 \\
\hline Beban Sedang & 16 & 20,3 \\
\hline Beban Ringan & 31 & 39,2 \\
\hline Tidak Ada Beban & 29 & 36,7 \\
\hline $\begin{array}{l}\text { Kualitas Hidup } \\
\text { Caregiver }\end{array}$ & & \\
\hline Rendah & 48 & 60,8 \\
\hline Tinggi & 31 & 39,2 \\
\hline
\end{tabular}

Sedangkan untuk kualitas hidup didapatkan bahwa kualitas hidup caregiver rendah $(60,8 \%)$. Hal ini sejalan dengan penelitian (Patricia, 2018) yang menyatakan bahwa sebagian besar Caregiver juga memiliki kualitas hidup yang rendah yakni sebesar $(53,2 \%)$. Hal ini mungkin terjadi karena adanya faktor lain yang dapat mempengaruhi kualitas hidup seperti kurangnya dukungan sosial, perjalanan penyakit dan hubungan antar anggota keluarga. Sejalan dengan hasil penelitian (Caqueo, 2009) yang mengemukakan bahwa variabel utama yang dapat mempengaruhi kualitas hidup adalah beban emosional, sebagai konsekuensi dari peran caregiver, kurangnya dukungan sosial, pekerjaan, perjalanan penyakit serta gangguan dalam kehidupan keluarga.

Hasil penelitian (Jusnita, 2013) tentang Profil Kepribadian dan Psychological Well Being mengatakan bahwa salah satu faktor yang menentukan keberhasilan dalam mengelaola stressor adalah karakteristik kepribadian yang sangat erat kaitannya dengan kondisi kesejahteraan psikologis. Stressor Caregiver juga mempengaruhi evaluasi terhadap ruang lingkup 
kehiduannya. Untuk mengukur kualitas hidup caregiver dengan tepat diperlukan penelitian lebih lanjut dengan menggunakan case control yang memiliki kelompok komparatif sehingga dapat mengukur dengan lebih baik tentang faktorfaktor yang mempengaruhi kualitas hidup Caregiver Skiofrenia.

Hubungan beban dengan kualitas hidup caregiver klien Skizofrenia

Tabel 3. Hubungan Beban dengan Kualitas Hidup Caregiver

\begin{tabular}{lccccccc}
\hline & \multicolumn{9}{c}{ Kualitas Hidup } & & & \\
Beban Caregiver & \multicolumn{2}{c}{ Rendah } & \multicolumn{2}{c}{ Ting } & Total & $\%$ & P Value \\
& $\mathbf{f}$ & $\%$ & $\mathbf{f}$ & $\%$ & & & \\
Beban Berat & 3 & 100,0 & 0 & 0,0 & 3 & 3,8 & \\
Beban Sedang & 14 & 87,5 & 2 & 12,5 & 16 & 20,3 & \\
Beban Ringan & 20 & 64,5 & 11 & 35,5 & 31 & 39,2 & 0,004 \\
Tidak Ada Beban & 11 & 37,9 & 18 & 62,1 & 29 & 36,7 & \\
TOTAL & 48 & 60,8 & 31 & 39,2 & 79 & 100,0 & \\
\hline
\end{tabular}

tabel 3 menunjukkan hasil analisis data didapatkan nilai $P$ value 0,004 yang artinya terdapat hubungan antara beban dengan kualitas hidup caregiver klien Skizofrenia. Bahwa semakin berat beban yang dirasakan oleh Caregiver maka kualitas hidupya akan semakin rendah.

Hal ini juga selaras dengan penelitian yang dilakukan oleh (Pahria, 2019) tentang hubungan positif antara beban dengan depresi keluarga bahwa semakin tinggi beban keluarga maka depresi yang terjadi akan semakin berat. Dalam hal ini depresi juga merupakan domain dari kualitas hidup yang diukur melalui dimensi psikologis.

Penelitian ini juga sejalan dengan penelitian yang dilakukan oleh (Triantoro, 2018) bahwa terdapat hubungan antara beban dengan kualitas hidup caregiver Skizofrenia dengan nilai $P$ value $(0,000)$ dan nilai koefisien korelasi sebesar $r=$ 0,799 hal ini menunjukkan adanya hubungan erat yang negatif artinya semakin tinggi beban maka akan semakin buruk kualitas hidup caregiver skizofrenia.

Menurut (Kaushik, 2013) merawat pasien Skizofrenia akan menghabiskan waktu perawatan setiap harinya sehingga dapat mengakibatkan tingginya beban dan buruknya kualitas hidup caregiver sehingga perlu dirumuskan Intervensi yang berfokus pada pengurangan waktu perawatan tersebut agar membantu caregiver mengurangi beban dan meningkatkan kualitas hidup mereka.

Bila ditinjau hubungan dimensi beban diantaranya beban secara fisik $(P$ value $=$ $0,033)$, beban secara emosional $(P$ value $=$ $0,008)$, beban ekonomi $(P$ value $=0,002)$ dan beban Sosial $(P$ value $=0,047)$ sebagaimana terdapat pada tabel 4 dapat dilihat bahwa semua dimensi beban tersebut memiliki hubungan dengan kualitas hidup Caregiver klien Skizofrenia.

Adanya hubungan antara beban Fisik dengan kualitas hidup dipengaruhi oleh karakterik caregiver; usia dimana caregiver terbanyak berada pada rentang usia 37 60 tahun $(75,9 \%)$ bahkan ada yang lebih dari 60 tahun $(13,9 \%)$ sehingga telah mengalami penurunan secara fisik yang berdampak terbatas aktifitas dalam merawat klien Skizofrenia di rumah. Hal ini sejalan dengan penelitian (Caqueo, 2009) bahwa caregiver yang lebih tua akan merasakan dan menerima beban yang lebih tinggi.

Hubungan beban emosional dengan kualitas hidup mungkin terjadi akibat perubahan kondisi emosional klien Skizofrenia di rumah. Selain beban fisik, emosional klien yang sering

berubah dapat memicu beban emosional yang dapat berkembang menjadi depresi pada keluarga (Roopchand-Martin and Creary-Yan, 2014).

Caregiver yang memiliki beban ekonomi berat berhubungan dengan kualitas hidup dimana hal ini mungkin terjadi karena meningkatnya kebutuhan ekonomi dalam hal pengobatan klien. Hasil karakteristik caregiver bahwa $60,8 \%$ 
penghasilan caregiver dibawah UMR. Hal ini sejalan dengan penelitian (Maryam, Riasmini and Suryati, 2012) bahwa selain waktu antara merawat dan peran lainnya serta beban ekonomi terkait biaya pengobatan klien.

Tabel 4. Hubungan Dimensi Beban dengan Kualitas Hidup Caregiver Skizofrenia $(n=79)$

\begin{tabular}{|c|c|c|c|c|c|c|}
\hline \multirow{3}{*}{ Variabel } & \multicolumn{4}{|c|}{ Kualitas Hidup } & \multirow{3}{*}{ P Value } & \multirow{3}{*}{ OR } \\
\hline & \multicolumn{2}{|c|}{ Rendah } & \multicolumn{2}{|c|}{ Tinggi } & & \\
\hline & $\mathbf{f}$ & $\%$ & $\mathbf{f}$ & $\%$ & & \\
\hline \multicolumn{7}{|l|}{ Beban Fisik } \\
\hline Beban Berat & 16 & 84,2 & 3 & 15,8 & & \\
\hline Beban Ringan & 32 & 53,3 & 28 & 46,7 & 0,033 & 4,667 \\
\hline $\begin{array}{l}\text { Total } \\
\text { Beban Emosio }\end{array}$ & 48 & 60,8 & 31 & 39,2 & & \\
\hline Beban Berat & 17 & 89,5 & 2 & 10,5 & & \\
\hline Beban Ringan & 31 & 51,7 & 29 & 48,3 & 0,008 & 7,952 \\
\hline $\begin{array}{l}\text { Total } \\
\text { Beban Ekonom }\end{array}$ & 48 & 60,8 & 31 & 39,2 & & \\
\hline Beban Berat & 35 & 76,1 & 11 & 23,9 & & \\
\hline Beban Ringan & 13 & 39,4 & 20 & 60,6 & 0,002 & 4,895 \\
\hline $\begin{array}{l}\text { Total } \\
\text { Beban Sosial }\end{array}$ & 48 & 60,8 & 31 & 39,2 & & \\
\hline Beban Berat & 13 & 86,7 & 2 & 13,3 & & \\
\hline Beban Ringan & 35 & 54,7 & 29 & 45,3 & 0,047 & 5,386 \\
\hline Total & 48 & 60,8 & 31 & 39,2 & & \\
\hline
\end{tabular}

Sedangkan beban sosial berhubungan dengan kualitas hidup mungkin terjadi akibat kurangnya dukungan sosial kepada caregiver dalam merawat anggota keluarga dengan Skizofrenia dimana hal ini sejalan dengan penelitian (Maryam, 2012) yang menyimpulkan bahwa terdapat hubungan yang bermakna antara status kesehatan, pengetahuan, kepuasan merawat, dukungan sosial, keluarga, dan status fungsional dengan beban keluarga dalam merawat anggota keluarga.

Namun bila dilihat nilai OR maka dapat disimpulkan beban yang paling beresiko adalah beban Emosional dengan OR $(7,952)$ artinya Caregiver yang memiliki beban emosional berat beresiko 7,952 kali mengalami kualitas hidup yang rendah.

Untuk meningkatkan pelayanan kesehatan jiwa diperlukan programprogram untuk meningkatkan koping keluarga melalui strategi pemecahan masalah bersama anggota keluarga, memberikan dukungan spiritual dan sosial dalam merawat anggota keluarga dengan Skizofrenia.

\section{KESIMPULAN}

Adanya hubungan yang signifikan antara beban dengan kualitas hidup caregiver Skizofrenia dengan nilai $P$ value 0,004 pada $\alpha=0,05$ dan dimensi beban yang paling beresiko menyebabkan kulitas hidup yang rendah adalah beban emosional dengan OR 7,952 sehingga diperlukan upaya promosi kesehatan pada keluarga untuk mengontrol emosional melaui strategi koping keluarga, dukungan spiritual dan dukungan sosial.

\section{REFERENSI}

Afriyeni, N. and Sartana (2017) 'Gambaran Tekanan dan Beban yang dialami oleh Keluarga sebagai Caregiver', Jurnal Ecopsy, 3, pp. 115-120.

Caqueo-Urizar, A., Jose Gutierrez, M. and Claudia Miranda, C. (2009) 'Quality of life in caregivers of patients with 
schizophrenia: A literature review', Biomed Central, 5, pp. 1-5. doi: 10.1186/1477-7525-7-84.

Fitrikasari, A. et al. (2012) 'Gambaran Beban Caregiver Penderita Skizofrenia di Poliklinik RAwat Jalan RSJ Amino Gondohutomo Semarang', Medica Hospitalia, 1(2), pp. 118-122.

Jusnita Nainggolan, N. and Hidajat, L. L. (2013) 'Profil Kepribadian dan Psychological Well-Being Caregiver Skizofrenia', Journal SOul, 6(1), pp. 21-42.

Kaushik, P. and Bhatia, M. S. (2013) 'Burden and Quality of Life in Spouses of Patients with Schizophrenia and Bipolar Disorder', Delhi Psychiatry Journal, 16(1), pp. 83-89.

Lam, P. C., NG, P. and Tori, C. (2013) 'Burdens and Psychological Health of Family Caregivers of People with Schizophrenia in Two Chinese Metropolitan Cities: Hong Kong and Guangzhou', Community Mental Health Journal.

Marnie L. Kramer-Kile et al. (2014) Chronic illness: impact and intervention. Edited by Marnie L. Kramer-Kile. Kevin Sullivan.

Maryam, R. S., Riasmini, N. M. and Suryati, E. S. (2012) 'Beban keluarga merawat lansia dapat memicu tindakan kekerasan dan penelantaran terhadap lansia', Jurnal Keperawatan Indonesia, 15(3), pp. 143-150.

Pahria, T., Sari, C. W. M. and Lisnawati (2019) 'Hubungan Beban dengan Depresi Keluarga yang Merawat Pasien Stroke di Rumah Sakit Al Islam Bandung', Jurnal Pendidikan Keperawatan Indonesia, 5(2), pp. 157166. doi: 10.17509/jpki.v5i2.19821.

Patricia, H. (2018) 'Karakteristik, Beban, dan Kualitas Hidup Pada Caregiver Klien Skizofrenia', Jurnal Kesehatan Medika Saitika, 9(1), pp. 9-23.

Patricia, H. and Irman, V. (2018) 'Faktorfaktor yang berhubungan dengan Kualitas Hidup pada Caregiver Klien Skizofrenia', Jurnal IImu Kesehatan (JIK), 2(April), pp. 42-49.

Rahmani, F. et al. (2019) 'International
Journal of Nursing Sciences Coping strategies of family caregivers of patients with schizophrenia in Iran: A cross-sectional survey', International Journal of Nursing Sciences. Elsevier Ltd, 6(2), pp. 148-153. doi: 10.1016/j.jinss.2019.03.006.

Riskesdas (2018) Hasil Utama Riset Kesehatan Dasar Kementrian Kesehatan Republik Indonesia, Badan Penelitian dan Pengembangan Kesehatan.

Roopchand-Martin, S. and Creary-Yan, S. (2014) Level of Caregiver Burden in Jamaican Stroke Caregivers and Relationship between Selected Sociodemographic Variables', West Indian Med Journal, 63(6), pp. 3-7. doi: 10.7727/wimj.2013.060.

Sari, Y. P., Sapitri, V. N. and Yaslina (2018) 'Faktor-faktor yang berhubungan dengan terjadinya kekambuhan pada penderita gangguan jiwa', Jurnal Kesehatan Perintis, 5(1), pp. 73-79.

Seng, B. K. et al. (2010) 'Validity and Reliability of the Zarit Burden Interview in Assessing Caregiving Burden', Annals of the Academy of Medicine, 39(May 2014), pp. 758-763.

Skevington, S. and Lotfy, M. (2004) 'The World Health Organization, $s$ WHOQOL-BREF quality of life assessment: Psychometric properties and results of the international field trial . A Report from the WHOQOL Group', Kluwer Academic, 13(August), pp. 299-310. doi: 10.1023/B.

Stuart, G.W., and Sundenen, S. J. (2013) Buku Saku Keperawatan Jiwa. 6th Editio. Edited by S. Louis. Mosby Year Book.

Triantoro, B. (2018) Relationship Caregiver Burden with Schizophrenia Caregiver's Quality of Life in Dr. RSJ. Radjiman Wediodiningrat Lawang. Universitas Airlangga.

WHO (2017) Investing in Mental Health. Department of Mental Health and Substance Dependence. Available at: https://www.who.int/mental_health/med ia/investing_mnh.pdf. 